\title{
TERMINOLOGI RUMAH ADAT DALAM LOKA SUMBAWA: SEBUAH TINJAUAN ANTROPOLINGUISTIK
}

\author{
Wawan Hermansyah \\ Universitas Mataram \\ wawanhermansyah774@yahoo.com
}

\begin{abstract}
Abstrak
Rumah adat Dalam Loka yang kini masih berdiri kokoh di tengah kota Sumbawa Besar, merupakan saksi sejarah yang memperlihatkan kejayaan Kesultanan Sumbawa pada zamannya. Kekayaan terminologi yang terdapat dalam rumah adat Dalam Loka, memberikan ruang bagi pengkaji bahasa dan budaya untuk memahami lebih dalam apa saja yang terjadi di masa lampau berdasarkan simbolsimbol nomina serta menyiratkan bagaimana kehidupan zaman dahulu sarat makna yang mendalam. Dengan demikian, untuk mengungkapkan bentuk-bentuk terminologi dan memahami nilai-nilai yang dimiliki dalam rumah adat Dalam Loka, perlu ditelusuri melalui pendekatan linguistik kebudayaan atau disebut dengan kajian antropolinguistik. Oleh karena itu, teori yang digunakan dalam penelitian ini yaitu teori antropolinguistik dan teori semiotik sosial. Adapun penelitian ini menggunakan pendekatan deskriptif kualitatif. Jenis dan sumber data yang digunakan dikelompokkan ke dalam dua jenis yaitu data primer dan data skunder. Metode yang digunakan dalam pengumpulan data yaitu metode simak dan metode cakap. Data dianalisis dengan menggunakan metode padan intralingual dan metode padan ekstralingual. Hasil dan pembahasan dalam penelitian ini, ditemukan bentukbentuk terminologi dalam rumah adat Dalam Loka Sumbawa berasal bahasa-bahasa nusantara, yaitu berasal dari bahasa Jawa, Makassar dan Melayu. Selain itu, adapun ditemukan bentuk-bentuk terminologi dalam rumah adat Dalam Loka Sumbawa yang berasal dari bahasa asing, seperti bahasa Arab dan bahasa Sanskerta. Konteks budaya bentuk-bentuk terminologi dalam rumah adat Dalam Loka Sumbawa menunjukkan keberadaan sebuah pradaban dengan sistem pemerintahan dan sistem kerajaan dalam bentuk aristokrasi. Tatanan pemerintahan yang bertumpu pada raja (sultan) adalah sebuah sistem yang mencakup adat, pemerintahan dan hukum.
\end{abstract}

Kata kunci: Rumah adat, Dalam Loka, antropolinguistik

\begin{abstract}
In Loka custom home that is still standing firm in the middle of the town of Sumbawa Besar is a historical witness that shows the glory of the Sultanate of Sumbawa in its time. Terminology richness that included in Dalam Loka custom home providing space for the language and culture reviewers to understand more deeply what happened in the past time based on the symbols of things and suggests how the ancient life with profound meaning. Thus, to express forms of terminology and understand the values held in Dalam Loka custom home, it is necessary to be traced through the linguistic approach or the study of culture called antropholinguistic. Therefore, the theory used in this research is antropolinguistic theory and social semiotic theory. This study used a qualitative descriptive approach. The types and sources of data used are classified into two types: primary data and secondary data. The methods used in the method of data collection were listening and conversation. The data were analyzed by using intralingual equivalence and ekstralingual equivalence method. The results and discussion of this research found that forms of terminology in the Dalam Loka custom home in Sumbawa derived from some languages, which is derived from the Javanese, Makassar and Malay languages. Moreover, as for other forms of terminology found in Dalam Loka custom home in Sumbawa derived from foreign languages, such as Arabic and Sanskrit language. The cultural context shapes the terminology in the Dalam Loka custom home in Sumbawa indicate the existence of a civilization with a system of government and the imperial system in the form of aristocracy. System of government rests on the king (sultan) is a system that includes customs, governance and law.
\end{abstract}

Keywords: Custome home, Dalam Loka, antropolinguistic

\section{PENDAhUluAN}

Indonesia adalah salah satu negara yang memiliki kebudayaan dan kearifan lokal yang yang beranekaragam, baik dalam bentuk kesenian, pakaian adat, rumah adat, bahasa daerah, atau kuliner khas daerah. 
Kebudayaan dan kearifan lokal tersebut terbentuk sebagai hasil dari proses interaksi antara manusia dengan lingkungan dalam rangka memenuhi berbagai kebutuhan. Manusia dalam kehidupannya mempunyai banyak kebutuhan hidup (Suriasumantri, 1996:261). Adanya kebutuhan hidup ini mendorong manusia untuk melakukan berbagai tindakan dan kebiasaan yang bermanfaat untuk mempertahankan dan mengembangkan cara hidupnya. Perkembangan cara hidup manusia dapat dilihat dari cara bagaimana mereka menata peradabannya (Sibarani, 2004:2).

Di Indonesia khususnya, perkembangan tersebut ditandai dengan banyaknya bendabenda peninggalan hasil budaya berupa bangunan (artifact) yang telah dibuat oleh nenek moyang terdahulu. Salah satu peninggalan yang yang dapat dilihat dan masih menjadi bagian simbolisasi kebudayaan di setiap daerah di nusantara adalah rumah adat. Keberadaan rumah adat sebagai bentuk material kebudayaan yang sangat beragam di setiap daerah/provinsi di Indonesia mempunyai makna yang penting dalam sejarah, warisan, dan kemajuan sebuah peradaban. Rumah adat dibangun tidak hanya dengan pertimbangan aspek fungsional-praktis, melainkan teramu dari berbagai aspek dan dimensi totalitas hidup manusia. Aspek-aspek tersebut meliputi aspek sosial, kultural, spiritual, estetis, dan lain-lain yang dikontruksikan sedemikian rupa dengan fungsi fisik dan nonfisiknya menjadi seni bangun yang mengagumkan.
Sebagai bagian dari wilayah Republik Indonesia, Provinsi Nusa Tenggara Barat (NTB), khususnya Kabupaten Sumbawa yang mayoritas dihuni oleh masyarakat etnis Samawa juga memiliki kearifan lokal dalam bentuk rumah adat. Sampai saat ini, masih ada beberapa rumah adat yang tersebar di beberapa wilayah Kabupaten Sumbawa. Namun, rumah adat Dalam Loka di Kabupaten Sumbawa yang menurut peneliti cukup representatif untuk mewakili keberadaan rumah adat yang ada di Sumbawa secara keseluruhaan karena rumah adat tersebut merupakan tempat tinggal Raja Sumbawa.

Rumah adat Dalam Loka kini masih berdiri kokoh di tengah kota Sumbawa Besar, merupakan saksi sejarah yang memperlihatkan kejayaan Kesultanan Sumbawa pada zamannya. Kekayaan terminologi (tata istilah) yang terdapat dalam setiap sudut rumah adat Dalam Loka, memberi ruang untuk memahami lebih dalam apa saja yang terjadi di masa lampau dan menyiratkan bagaimana kehidupan zaman dahulu sarat makna yang mendalam. Selain itu, eksistensi rumah adat Dalam Loka yang masih terlihat memberi gambaran tentang detail bagaimana agama yang dianut serta gambaran filosofi hidup masyarakat Samawa.

Pada rumah adat Dalam Loka terdapat nama dan istilah serta bentuk arsitektur khas yang melekat pada setiap komponennya. Melalui arsitektur khas tersebut, para leluhur dapat membahasakan 
jati dirinya sebagai orang Sumbawa (tau Samawa), baik sebagai individu maupun sebagai bagian dari masyarakat. Salah satu contoh terminologi rumah adat Dalam Loka yaitu terekam pada penamaan arsitektur ruangannya yang disebut dengan lunyuk emas 'ruang pertemuan (khusus wanita)'. Kata lunyuk berasal dari nama sebuah tempat atau nama sebuah ruangan, seperti halnya nama salah satu desa di Kabupaten Sumbawa yaitu Desa Lunyuk (tempat salah satu pemukiman penduduk asli etnis Sumbawa). Sementara kata emas dalam KBBI (2012) yaitu: 1) logam mulia berwarna kuning yang dapat ditempa dan dibentuk, biasa dibuat perhiasan seperti cincin, kalung, 2) uang; harta duniawi, 3) sesuatu yang tinggi mutunya (berharga; bernilai). Jadi, konsep emas pada bentuk lunyuk emas sangat sesuai dengan nilainilai tentang keperempuanan, misalnya perempuan dianggap sebagai sesuatu yang berharga, berkilau, sebagai perhiasan (karena kecantikannya) dan banyak dicari-cari orang. Dengan demikian, istilah lunyuk emas 'ruang pertemuan (khusus wanita)' menunjukkan bahwa pada kepemimpinan Sultan Sumbawa mengakui peran dan eksisitensi perempuan dalam kehidupan masa itu. Hal tersebut sesuai dengan ajaran agama Islam yang dianut oleh masyarakat Sumbawa.

Dalam konteks kekinian, bentuk dan nilai-nilai yang terkandung dalam salah satu komponen rumah adat Dalam Loka seperti cuplikan data di atas, sebagian besar sudah tidak dipahami lagi oleh generasi muda. Pesatnya pembangunan pada pelbagai aspek kehidupan masyarakat yang diiringi dengan persebaran nilai-nilai baru serta ilmu pengetahuan dan teknologi, menyebabkan nilainilai tradisi lokal terdesak, tidak dipatuhi, tidak dipahami bahkan terdegradasi. Selain itu, tidak mudah menata ulang identitas kedaerahan di tengah kepatuhan total terhadap kesadaran kebangsaan. Kebutuhan sadar diri atas nilai-nilai kelokalan terkesan berat dan cenderung dipaksakan demi pengakuan dan pengawalan atas kesadaran bernegara. Cara pandang masyarakat tentang adat dan kelokalan masih dibayangi masa lalu yang kolot dan feodal, sistem nilai yang irasional, dan anggapan ketidakmampuan mengikuti perubahan. Hal ini diperkuat dengan karakteristik masyarakat Samawa yang begitu terbuka terhadap halhal baru, sehingga semakin mempertipis kesadaran dan kedirian masyarakat Samawa dari akar identitas pradabannya. Peneliti tidak bermaksud membangun paradigma bahwa pengentalan identitas lokal sebagai pembangkangan atas rasa nasionalisme, namun perlu ada penguatan kesadaran bahwa bangsa ini dibangun di atas keanekaragaman.

Penelitian ini bersifat deskriptif kualitatif, yakni berusaha menggambarkan secara sistematis, faktual dan akurat mengenai fakta-fakta tentang terminologi dalam rumah adat Dalam Loka Sumbawa. Data diperoleh dari hasil pengamatan, hasil wawancara, hasil pemotretan, analisis 
dokumen dan catatan lapangan. Hasil analisis data berupa pemaparan mengenai situasi yang diteliti dan disajikan dalam bentuk uraian deskriptif.

Untuk memperoleh data yang memadai, maka dalam penelitian ini ditetapkan dua metode pengumpulan data, yakni (1) metode simak, dan (2) metode cakap. Metode simak digunakan untuk mengamati fenomena-fenomena kebahasaan, yakni berupa istilah-istilah yang terdapat dalam rumah adat Dalam Loka Kabupaten Sumbawa.

Data dalam penelitian ini dikelompokkan ke dalam dua jenis yaitu data primer dan data skunder. Data primer adalah data yang diperoleh atau dikumpulkan oleh peneliti secara langsung dari sumber datanya. Data primer dalam penelitian ini berupa terminologi (tata istilah) yang terdapat dalam rumah adat Dalam Loka Sumbawa. Data skunder adalah data yang diperoleh atau data yang dikumpulkan peneliti dari berbagai sumber yang telah ada seperti buku, laporan penelitian, dan jurnal. Selain itu, data skunder dalam penelitian ini juga didapatkan dari hasil wawancara dengan informan. Informan dalam penelitian ini yaitu, pengurus Lembaga Adat Tanah Samawa (LATS), tokoh adat dan budaya di Kabupaten Sumbawa yang di anggap oleh peneliti memiliki kompetensi memadai terkait dengan ikhwal penelitian.

Metode yang digunakan dalam penganalisisan data dalam penelitian ini yaitu metode padan intralingual dan metode padan ekstralingual. Metode padan intralingual adalah metode analisis dengan cara menghubung-bandingkan unsur-unsur yang bersifat lingual, baik yang terdapat dalam satu bahasa maupun beberapa bahasa yang berbeda (Mahsun: 2005:118). Metode padan menggunakan teknik hubung banding menyamakan (HBS) dan hubung banding membedakan (HBB). Selain dua teknik itu, metode ini mempunyai satu teknik lagi yaitu teknik hubung banding menyamakan hal pokok (HBSP), yaitu teknik yang bertujuan untuk mencari kesamaan hal pokok dari pembedaan dan penyamaan yang dilakukan dengan menerapkan teknik HBS dan HBB. Tujuan akhir dari banding menyamakan atau membedakan yaitu menemukan kesamaan pokok di antara data yang diperbandingkan itu. Secara khusus, metode padan intralingual akan dimanfaatkan peneliti untuk menganalisis terminologi (tata istilah) yang terdapat dalam rumah adat Dalam Loka Sumbawa. Selanjutnya, metode padan ekstralingual adalah metode yang digunakan untuk menganalisis unsur yang bersifat ekstralingual, seperti menghubungkan masalah bahasa dengan hal yang berada di luar bahasa (Mahsun, 2007:120). Metode padan ekstralingual ini digunakan oleh peneliti untuk menganalisis nilai-nilai kultural yang terkandung dalam terminologi dan bentuk arsitektur rumah adat Dalam Loka Sumbawa.

Peneliti menganggap kajian tentang hal ini penting dilakukan, selain sebagai upaya pendokumentasian bahasa, peneliti juga 
menganggap bahwa kekayaan terminologi (tata istilah) dalam bentuk arsitektur khas yang melekat pada rumah adat Sumbawa perlu dieksplorasikan kepada masyarakat luas sebagai bentuk dedikasi dan pengakuan atas eksistensi kebudayaan daerah. Selain itu, belum adanya penelitian tentang rumah adat Dalam Loka dari sudut pandang antropolinguistik merupakan dasar yang digunakan untuk melaksanankan penelitian ini.

\section{KONSEP DAN KERANGKA TEORI Konsep}

Dalam penelitian ini, ada dua konsep dasar yang menjadi rujukan empiris untuk memahami fenomena objek penelitian. Kedua konsep dasar tersebut adalah konsep terminologi rumah adat dan konsep rumah adat Dalam Loka Sumbawa.

\section{Terminologi Rumah Adat}

Terminologi (tata istilah) adalah perangkat asas dan ketentuan pembentukan istilah serta kumpulan istilah yang dihasilkannya. Misalnya; nabolisme, pasar modal, demokrasi, pemerataan, laik terbang dan lain-lain. Istilah adalah kata atau frasa yang dipakai sebagai nama atau lambang dan yang dengan cermat mengungkapkan makna konsep, proses, keadaan, atau sifat yang khas dalam bidang ilmu pengetahuan, teknologi, dan seni. Dalam peristilahan dikenal juga istilah umum dan istilah khusus. Istilah umum adalah istilah yang berasal dari bidang tertentu, yang karena dipakai secara luas, menjadi unsur kosakata umum, misalnya; anggaran belanja, daya, radio, nikah, takwa. Istilah khusus adalah istilah yang maknanya terbatas pada bidang tertentu saja, misalnya; morfologi, sintaksis, fonologi dan lain-lain.

Bentuk istilah terkait penelitian ini ada dua bentuk istilah yaitu monomorfemis dan polimorfemis.

Monomorfemis (Monomorphemic) terjadi dari suatu morfem (Kridalaksana, 2008:157). Morfem merupakan satuan bunyi terkecil yang relatif stabil dan yang tidak dapat dibagi atas bagian bermakna yang lebih kecil misalnya (ter-), (di-), dan sebagainya (Kridalaksana, 2008:158). Menurut Koentjono (1982:180) satu atau lebih morfem akan menyusun sebuah kata. Kata dalam hal ini ialah satuan gramatikal bebas yang terkecil. Kata bermorfem satu disebut kata monomorfemis dengan ciri-ciri dapat berdiri sendiri sebagai kata, mempunyai makna dan berkategori jelas. Polimorfemis adalah kata bermorfem lebih dari satu. Bentuk polimorfemis yaitu (1) pengimbuhan/afiksasi (penambahan afiks) yaitu proses pembubuhan afisk pada sebuah dasar atau bentuk dasar, afiks adalah sebuah bentuk, biasanya berupa morfem terikat yang diimbuhkan pada sebuah dasar dalam pembentukan kata (Chaer, 2007:177), (2) reduplikasi adalah proses morfemis yang mengulang bentuk dasar, baik secara keseluruhan, secara sebagian (parsial), maupun dengan perubahan bunyi (Chaer, 2007:182), (3) komposisi adalah hasil dan proses penggabungan morfem dasar, baik yang bebas 
maupun yang terikat, sehingga terbentuk sebuah kontruksi yang memiliki identitas leksikal yang berbeda, atau yang baru (Chaer, 2007:185), (4) frasa lazim didefinisikan sebagai satuan gramatikal yang berupa gabungan kata yang bersifat nonpredikatif, atau lazim juga disebut gabungan kata yang mengisi salah satu fungsi sintaksis di dalam kalimat (Chaer, 2007:222). Jenis frase digolongkan menjadi empat yaitu, frase eksosentrik, frase endosentrik (frase subordinatif atau frase modifikasi), frase koordinatif, dan frase apositif.

\section{Rumah Adat Dalam Loka Sumbawa}

Konsep rumah adat sebagai bangunan rumah yang melambangkan kebudayaan dan ciri khas masyarakat setempat. Budihardjo (1994:57) mendefinisikan rumah adalah aktualisasi diri yang diejawantahkan dalam bentuk kreativitas dan pemberian makna bagi kehidupan penghuninya. Frick (2008:2) mengemukakan bahwa rumah adat sebagai karya arsitektur bukan hanya sekedar susunan material dan struktur bangunan yang terletak di suatu site/lokasi, namun lebih merupakan suatu manifestasi aspek-aspek ritual, kultural, sosial, materialisasi, teknik dan keahlian. Dalam persfektif yang hampir sama, Haryadi dan Setiawan (2010) faktor relegi dan kepercayaan dipandang sangat berpengaruh pada bentuk dan pola rumah bahkan dalam masyarakat tradisional cenderung merupakan faktor dominan dibandingkan faktorfaktor lainnya.
Hingga saat ini masih banyak suku atau daerah-daerah di Indonesia yang masih mempertahankan rumah adat sebagai usaha untuk memelihara nilai-nilai budaya yang kian tergeser oleh budaya modernisasi. Biasanya rumah adat tertentu dijadikan sebagai aula (tempat pertemuan), museum atau dibiarkan begitu saja sebagai obyek wisata. Bentuk dan arsitektur rumah-rumah adat di Indonesia masing-masing daerah memiliki bentuk dan arsitektur berbeda sesuai dengan nuansa adat setempat. Rumah adat pada umumnya dihiasi ukiran-ukiran indah, pada jaman dulu, rumah adat yang tampak paling indah biasa dimiliki para keluarga kerajaan atau ketua adat setempat menggunakan kayu-kayu pilihan dan pengerjaannya dilakukan secara tradisional melibatkan tenaga ahli di bidangnya. Banyak rumah adat yang saat ini masih berdiri kokoh dan sengaja dipertahankan serta dilestarikan sebagai simbol budaya Indonesia.

Dalam Loka berasal dari kata Dalam yang artinya istana, komplek tempat tinggal raja dan keluarganya, sedangkan Loka berarti tua. Dengan demikian, Dalam Loka berarti istana tua. Dalam Loka merupakan representasi dari keberadaan sebuah kerajaan yang pernah eksis pada jaman dahulu. Dalam Loka dibangun pada tahun 1885, diprakarsai oleh Sultan Muhammad Jalaluddin Syah III yang menjadi Sultan ke16. Dalam Loka berbentuk rumah panggung dengan luas bangunan 904 M2, istana yang dibangun dengan bahan kayu ini memiliki 
filosofi "adat berenti ko syara, syara barenti ko kitabullah", yang berarti semua aturan adat-istiadat maupun nilai-nilai dalam sendi kehidupan masyarakat Sumbawa harus bersemangatkan pada syariat Islam.

\section{Kerangka Teori Antropolinguistik}

Bahasa dan kebudayaan memiliki hubungan yang sangat erat. Keduanya saling memengaruhi, saling mengisi, dan berjalan berdampingan. Bahasa adalah bagian dari kebudayaan sehingga mempelajari suatu bahasa secara tidak langsung juga mempelajari kebudayaan. Artinya, bahasa harus dipelajari dalam konteks kebudayaan dan demikian sebaliknya kebudayaan baru bisa dipelajari melalui bahasa. Eratnya hubungan antara bahasa dan kebudayaan memunculkan kajian untuk mengetahui hubungan tersebut. Dalam kebudayaan, bahasa menduduki tempat yang unik dan terhormat. Selain sebagai unsur kebudayaan, bahasa juga berfungsi sebagai sarana terpenting dalam pewarisan, pengembangan dan penyebarluasan kebudayaan. Cakupan kajian yang berkaitan dengan bahasa sangat luas, karena bahasa mencangkup hampir semua aktivitas manusia. Hingga akhirnya linguistik memperlihatkan adanya pergerakan menuju kajian yang bersifat multidisplin, salah satunya adalah antropologi linguistik.

Kajian tentang hubungan antara bahasa dan kebudayaan pada umumnya dilihat dari ilmu yang mepelajarinya. Antropologi sebagai ilmu yang mengkaji kebudayaan dan linguistik sebagai ilmu yang mengkaji bahasa. Selanjutnya, linguistik dan antropologi bekerja sama dalam mempelajari hubungan bahasa dan aspek-aspek budaya dengan sebutan antropolinguistik. Antropolinguistik maksudnya cabang linguistik yang mepelajari variasi dan penggunaan bahasa dalam hubungannya dengan perkembangan waktu, perbedaan tempat komunikasi, sistem kekerabatan, pengaruh kebiasaan etnik, kepercayaan, etika berbahasa, adat istiadat dan pola-pola kebudayaan lain dari suatu suku bangsa (Sibarani, 2004:49-50).

Antropolinguistik adalah cabang linguistik yang menaruh perhatian pada: a) pemakaian bahasa dalam konteks sosial dan budaya yang luas, dan b) peran bahasa dalam mngembangkan dan mempertahankan aktifitas budaya serta struktur sosial. Dalam hal ini, antropolinguistik memandang bahasa melalui konsep antropologi yang hakiki dan melalui budaya, menemukan makna di balik penggunaannya, serta menemukan bentuk-bentuk bahasa, register, dan gaya. Dalam kaitan bahasa dengan antropologi, bahasa merupakan bagian dari kebudayaan (Halliday, dalam Suryatna, 1996:59). Antropolinguistik menitikberatkan pada hubungan antara bahasa dengan kebudayaan dalam suatu masyarakat (Sibarani, 2004:50). Selanjutnya, Kridalaksana menggunakan istilah kajian antropolinguistik ini adalah kajian linguistik kebudayaan. Linguistik kebudayaan adalah cabang ilmu lingustik yang mempelajari variasi dan pemakaian bahasa dalam hubungannya 
dengan pola kebudayaan dan ciri-ciri bahasa yang berhubungan dengan kelompok sosial, agama, pekerjaan dan kekerabatan (Sibarani dan Henry, 1993:128). Linguistik kebudayaan merupakan kajian tentang kedudukan dan fungsi bahasa di dalam konteks sosial dan budaya secara lebih luas yang memiliki peran untuk membentuk dan mempertahankan praktik-praktik kebudayaan dan struktur sosial masyarakat (Beratha 1998:42).

Menurut Mbete (2009:2) banyak leksikon-leksikon bermakna dan berfungsi referensial di Indonesia, yakni khazanah leksikon yang referensi nyatanya dapat dilacak, dijejaki, dibuktikan secara empirik atau kasat mata, karena dapat ditemukan di lapangan, daya cipta dan kode-kode lingual kata, ungkapan-ungkapan, dan pemberdayaan wacana bahasa lokal sangat penting sebagai strategi pelestarian bahasa dan sumber daya alami lokal. Cara demikian menjadi solusi mengatasi persoalan keterancaman sumber daya bahasa dan budaya daerah.

Kebudayaan secara umum tercermin dalam tiga hal, yaitu perilaku, nilai, dan artefak (Koentjaraningrat, 2009:150). Menurut Masinambow (1998:1) artefak adalah benda fisik yang mengalami olahan olah tangan untuk memenuhi suatu keperluan tertentu. Misalnya, batu yang dibelah dua agar sisi pecahannya yang tajam digunakan untuk memutus tali disebut artefak. Sebuah gedung besar juga disebut artefak karena dibangun dengan tujuan untuk dihuni manusia, atau dipakai sebagai tempat berkumpul manusia, atau sebagai tempat menyimpan barang. Hal yang penting adalah bahwa keberadaan artefak adalah akibat perilaku dan tindakan manusia yang didorong oleh motivasi dan pemikirannya. Oleh karena itu, artefak bukanlah sesuatu yang terisolasi, tetapi merupakan salah satu unsur dari suatu sistem sehingga makna yang terkandung di dalamnya bersifat sistematis pula. Hal ini juga berarti bahwa makna artefak dapat ditentukan oleh sistem, oleh artefak itu sendiri, dan oleh manusia yang membuat artefak itu, atau yang mengaitkan unsur fisik dari lingkungan dengan makna tertentu. Hal-hal ini semua telah menjadi objek pemikiran teoretis dan secara sistematis dianalisis oleh semiotik dengan bertumpu pada tanda (sign) sebagai konsep pokoknya.

Jika dilihat dari berbagai definisi yang dikemukakan oleh para ahli kebudayaan di atas, maka tidak terlalu keliru kiranya mengartikan kebudayaan sebagai sehimpunan nilai-nilai yang oleh masyarakat pendukungnya dijadikan acuan bagi perilaku warganya. Nilai-nilai itu juga berpengaruh sebagai kerangka untuk membentuk pandangan hidup yang kemudian relatif menetap dan tampil melalui pilihan warga budaya itu untuk menentukan sikapnya terhadap berbagai gejala dan peristiwa kehidupan. Nilai-nilai itu pada sendirinya baru merupakan acuan dasar yang keberlakuannya disadarkan melalui ikhtiar pendidikan sejak dini, seperti misalnya dalam mem- 
bedakan baik dan buruk melalui normanorma sebagai pengatur kepantasan perilaku. Oleh karena itu, budaya suatu masyarakat dapat ditelusuri melalui bahasanya. Dengan demikian, penelitian bahasa suatu masyarakat dapat dimanfaatkan untuk mengungkap budaya masyarakat tersebut. Penggunaan teori antropolinguistik dalam penelitian ini didasari atas pertimbangan bahwa kajian antropolinguistik juga menggambarkan mengenai inspirasi intelektual (intellectual inspiration) yang berasal dari hubungan interaksional, berdasarkan pada perspektif aktifitas dan pemikiran manusia. Rumah adat adalah salah satu elemen penting dalam hal mewakili inspirasi intelektual yang diejawantahkan dalam bentuk dan karakteristik arsitektur yang khas.

Dalam penelitian ini, kajian antropolinguistik dimanfaatkan untuk memolakan kerangka budaya masyarakat yang terdapat di wilayah penelitian. Antropolinguistik pada hakikatnya berfokus pada kajian untuk mengungkap hakikat bahasa yang terdiri atas bentuk dan makna dibalik bentuk yang ada tersebut. Dengan demikian, penelitian ini berfokus pada kajian bahasa untuk mendeskripsikan kebudayaan masyarakat Sumbawa. Upaya menemukan kebudayaan masyarakat Sumbawa dilakukan dengan cara mengkaji bahasa yang terdapat dalam terminolgi rumah adat Dalam Loka Sumbawa. Aspek bahasa yang menjadi kajian penelitian ini berupa istilah-istilah yang berhubungan dengan nama benda, kata, kelompok kata, serta istilah-istilah lain yang berhubungan dengan proses budaya yang terjadi dalam pemanfaatan rumah adat tersebut.

\section{Teori Semiotik Sosial}

Konsep semiotik mulanya berasal dari konsep tanda yang berhubungan dengan istilah penanda (semainon) dan petanda (semainomenon) dalam bahasa Yunani. Dengan demikian, secara umum dapat dikatakan bahwa semiotik adalah ilmu yang mempelajari sistem tanda, seperti bahasa, kode, sinyal, dan sebagainya. (Halliday dan Hasan, 1994:3) Sementara, kata sosial berkaitan dengan konsep sistem sosial dan konsep struktur sosial. Lebih lanjut, Halliday memberi tekanan pada keberadaan konteks sosial bahasa, yakni fungsi sosial yang menentukan bentuk bahasa dan bagaimana perkembangannya (Halliday, 1977). Bahasa sebagai salah satu dari sejumlah sistem makna yang lain seperti tradisi, sistem mata pencarian, dan sistem sopan santun secara bersama-sama membentuk budaya manusia. Tidak ada fenomena bahasa yang vakum sosial, tetapi ia selalu berhubungan erat dengan aspek-aspek sosial. Dalam proses sosial itu, menurut Halliday, konstruk realitas tidak dapat dipisahkan dari konstruksi sistem semantis tempat realitas itu dikodekan.

Sementara itu, semiotik sosial adalah semiotik yang secara khusus menelaah sistem tanda yang dihasilkan oleh manusia yang berwujud lambang, baik berupa kata 
maupun rangkaian kata atau kalimat. Semiotik sosial lebih cenderung melihat bahasa sebagai sistem tanda atau simbol yang sedang mengekspresikan nilai dan norma kultural serta sosial suatu masyarakat tertentu di dalam suatu proses sosial kebahasaan. Semiotik sosial tidak lagi melihat bahasa sebagai suatu entitas yang secara otomistis dirujuk sebagai hubungan antara 'yang ditandai' dan 'yang menandai'. Semiotik sosial lebih melihat bahasa sebagai suatu realitas, realitas sosial, dan sekaligus sebagai realitas semiotik (Santoso, 2003:6).

Sebagai suatu realitas, bahasa adalah sebuah fenomena berupa pengalaman fisik, logis, psikis penuturnya dalam konteks situasi dan konteks budaya tertentu. Bahasa sebagai realitas sosial, artinya bahasa merupakan fenomena sosial yang digunakan oleh penuturnya untuk berinteraksi dan berkomunikasi dalam konteks situasi dan budaya tertentu. Bahasa adalah realitas semiotika yang berarti bahasa merupakan simbol yang mewujudkan realitas dan realitas sosial dalam konteks situasi dan budaya tertentu. Dengan demikian, ketiga unsur tadi merupakan satu kesatuan dalam mengekspresikan makna atau fungsi sosial tertentu. Oleh karena itu, keberadaan rumah adat sebagai simbolisasi kebudayaan dan cermin ke- hidupan masyarakat Sumbawa kala itu, dari segi kebahasaan dapat dikatakan memiliki makna tersurat dan makna tersirat. Makna tersurat adalah makna bahasa yang dapat dilihat dalam kamus, sedangkan makna tersirat maksudnya adalah makna bahasa yang tidak terdapat dalam kamus, tetapi dapat ditelusuri dengan melihat konteksnya (Riana, 2003:10).

Penelitian ini berusaha menganalisis dan mengartikan makna dari objek yang diteliti berdasarkan fakta di lapangan. Kekayaan istilah yang melekat pada setiap sudut rumah adat Dalam Loka Sumbawa merupakan sebuah tanda yang mewakili sistem sosial dan sistem pemerintahan kerajaan Sumbawa pada zamannya. Formulasi bahasa sebagai semiotik sosial berarti menafsirkan bahasa dalam konteks sosiokultural tempat kebudayaan itu ditafsirkan dalam terminologis semiotis sebagai sebuah sistem informasi.

\section{PEMBAHASAN}

Bentuk-Bentuk Terminologi dalam

Rumah Adat Dalam Loka

Berdasarkan temuan data di lapangan, adapun bentuk-bentuk terminologi dalam rumah adat Dalam Loka Sumbawa dapat dikemukan sebagai berikut.

\begin{tabular}{|c|l|l|}
\hline No. & \multicolumn{1}{|c|}{ Kata/Istilah } & \multicolumn{1}{c|}{ Glos } \\
\hline 1. & Bala bulo & $\begin{array}{l}\text { 'Bangunan (bangsawan) pendukung istana Dalam } \\
\text { Loka yang khusus digunakan oleh putra dan putri } \\
\text { sultan' }\end{array}$ \\
\hline 2. & Bala kemar & 'Bangunan induk Dalam Loka' \\
\hline 3. & Bale pamaning & 'Bangunan tempat mandi sultan dan keluarga' \\
\hline 4. & Dining panili & 'Dinding pembatas pandangan ke ruangan dalam' \\
\hline
\end{tabular}


RETORIKA: Jurnal Ilmu Bahasa, Vol. 2, No.2 Oktober 2016, 303

\begin{tabular}{|c|l|l|}
\hline 5. & Lawang rare & $\begin{array}{l}\text { 'Gerbang pembatas antara mesjid Nurul Huda } \\
\text { dengan Dalam Loka' }\end{array}$ \\
\hline 6. & Lunyuk agung & 'Ruang pertemuan, tempat upacara kesultanan' \\
\hline 7. & Lunyuk emas & 'Ruang pertemuan (khusus wanita)' \\
\hline 8. & Paladang & 'Ruang tunggu (lobi)' \\
\hline 9. & Parangin & 'Ruang tunggu (tempat duduk) sebelah timur' \\
\hline 10. & Sanapir kamutar & 'Ruang dapur' \\
\hline 11. & Sarapo kamutar & $\begin{array}{l}\text { 'Bangunan semipermanen (bongkar-pasang) yang } \\
\text { dibangun ketika dilaksanakannya acara-acara adat' }\end{array}$ \\
\hline 12. & Sarumung belo & $\begin{array}{l}\text { 'Kamar mandi untuk penghuni istana (selain sultan) } \\
\text { dan tamu' }\end{array}$ \\
\hline 13. & Tangke & $\begin{array}{l}\text { 'Ruang tunggu (tempat menitipkan/meletakkan } \\
\text { segala jenis senjata tajam) sebelah barat' }\end{array}$ \\
\hline 14. & Tete gasa & $\begin{array}{l}\text { 'Tangga utama (jalur masuk/naik) yang terletak di } \\
\text { bagian depan' }\end{array}$ \\
\hline 15. & Tete sawai & \begin{tabular}{l} 
'Tangga yang terletak di bagian belakang' \\
\hline
\end{tabular}
\end{tabular}

Kajian Linguistis Bentuk-Bentuk Terminologi dalam Rumah Adat Dalam

\section{Loka Sumbawa}

\section{a. Bala Kemar dan Bala Bulo}

Kata bala dalam kamus bahasa SamawaIndonesia adalah rumah bangsawan, sedangkan kata kemar berarti kembar, sehingga bala kemar 'bangunan induk Dalam Loka' yaitu rumah sekaligus sebagai pusat pemerintahan dan tempat tinggal sultan beserta keluarganya. Salah satu alasan dibangunnya bala kemar adalah karena adanya desakan dari rakyat yang ingin melihat tempat tinggal pemimpinnya berbeda dengan rumah-rumah lainnya. Sebagaimana diketahui bahwa istana Raja Sumbawa, terutama dari masa Sultan $\mathrm{Mu}$ hammad Kaharuddin II sampai dengan Sultan Amrullah, hampir tidak ada bedanya dengan rumah masyarakat biasa. Sultansultan Sumbawa pada saat itu hidup dalam kesederhanaan dan benar-benar memfungsikan dirinya sebagai pelayan dan pelindung masyarakat. Bala kemar yang menjadi tempat tinggal sultan dan sebagai pusat kegiatan pemerintahan penuh dengan simbol-simbol yang mengarahkan, mengingatkan dan membimbing sultan untuk mampu mengayomi rakyatnya sesuai dengan syariat Islam. Konsep bangunannya yang bergandeng dua, melambangkan dua kalimat syahadat, yaitu sebagai salah satu rukun dalam Islam. Tempat tersebut berdiri kokoh di atas sembilan puluh sembilan tiang sebagai simbol asma'ul husna (sifatsifat Allah)

Selain bala kemar, terdapat pula bala bulo 'bangunan (bangsawan) pendukung istana Dalam Loka yang khusus digunakan oleh putra dan putri sultan' yang berbentuk rumah dua susun, lantai pertama yang sejajar dengan bala kemar sebagai tempat putra/putri raja bermain, sedangkan lantai dua sebagai tempat permaisuri beserta istri para bangsawan menyaksikan pertunjukkan yang dilangsungkan di lapangan istana.

b. Tete Gasa dan Tete Sawai 
Tete 'titian' + gasa 'gasal/ganjil' yaitu tangga utama untuk naik atau turun ke dalam bala rea. Tete gasa 'tangga utama (jalur masuk/naik) yang terletak di bagian depan' berbeda dengan tangga biasa pada umumnya, tangga ini berupa lantai kayu yang dimiringkan hingga menyentuh tanah. Lantai kayu tersebut ditempeli oleh potongan kayu sebagai penahan pijakan. Secara harfiah, tete gasa adalah titian dalam jumlah ganjil yang digunakan untuk menyebrang dari suatu tempat ke tempat yang lain. Pada tete gasa terdapat dua puluh lima anak tangga yang menandakan jumlah nabi dan rasul dalam agama Islam. Tete gasa dibuat dengan konsep 'peruak' (tanjakan) sehingga saat berjalan di atasnya posisi badan sedikit merunduk sebagai bentuk penghormatan terhadap sultan.

Tete 'titian' + sawai 'perempuan' adalah tangga belakang bala kemar yang digunakan untuk membawa makanan naik atau turun ke Istana. Disebut tete sawai 'tangga yang terletak di bagian belakang' karena tangga ini khusus untuk wanita saja.

\section{c. Lunyuk Agung dan Lunyuk Emas}

Kata lunyuk saat ini dikenal sebagai sebuah nama kecamatan di Kabupaten Sumbawa, sedangkan agung dalam KBBI (2012) berarti besar, mulia, luhur. Kaitannya dengan keberadaan lunyuk agung 'ruang pertemuan, tempat upacara kesultanan' yang difungsikan sebagai ruang musyawarah khusus laki-laki menunjukan bahwa budaya demokrasi sudah berlansung lama di Sumbawa. Sikap musyawarah dianggap sebagai suatu yang mulia dan luhur karena dapat memecahkan permasalahan dengan menemukan solusi yang terbaik berdasarkan keputusan yang disepakati bersama.

Kata lunyuk seperti halnya pada bentuk lunyuk agung belum ditemukan konsepnya selain sebagai sebuah nama wilayah kecamatan di Kabupaten Sumbawa. Sementara kata emas dalam KBBI (2012) logam mulia berwarna kuning yang dapat ditempa dan dibentuk, biasa dibuat perhiasan seperti cincin, kalung, 2) uang; harta duniawi, 3) sesuatu yang tinggi mutunya (berharga; bernilai). Jadi, konsep emas pada bentuk lunyuk emas 'ruang pertemuan (khusus wanita)' sangat sesuai dengan nilai-nilai tentang keperempuanan, misalnya perempuan dianggap sebagai sesuatu yang berharga, berkilau, sebagai perhiasan (karena kecantikannya) dan banyak dicari-cari orang.

\section{d. Paladang, Parangin dan Tangke}

Paladang (pal + adang) 'ruang tunggu (lobi)' yang berfungsi sebagai tempat menunggu bagi tamu-tamu istana. Kata adang dalam Kamus Samawa-Indonesia (2009) memiliki arti hadang, menghadang.

Parangin (pa + angin) 'ruang tunggu (tempat duduk) sebelah timur' merupakan bagian dari paladang sebelah timur yang digunakan untuk menunggu tamu-tamu raja.

Tangke 'ruang tunggu (tempat menitipkan/meletakkan segala jenis senjata tajam) sebelah barat' adalah bagian pala- 
dang sebelah barat yang digunakan sebagai tempat meletakkan senjata tajam dan barang-barang bawaan lainnya yang sekiranya tidak diperkenankan untuk dibawa masuk ke dalam ruangan istana. Meletakkan senjata tajam pada tangke dianggap sebagai bentuk penghormatan tamu terhadap tuan rumah..

\section{e. Sanapir Kamutar dan Sarapo Kamutar}

Sanapir 'dapur' + kamutar (kaN + putar) 'ruang dapur', merupakan dapur khusus yang disiapkan untuk menjamu tamu yang datang di luar jam makan. Tamu istana yang datang biasanya dari Kedatuan Taliwang, Jereweh atau Seran. Oleh karena itu, sanapir kamutar adalah bentuk dari kesigapan dan antisipasi kedatangan tamutamu tersebut.

Sarapo $(s a+$ rapo $)+$ kamutar $(k a N+$ putar) 'bangunan semipermanen (bongkarpasang) yang dibangun ketika dilaksanakannya acara-acara adat' adalah bangunan pelengkap pendukung dalam loka yang sifatnya situasional karena dibangun pada saat akan diadakan acara-acara adat.

\section{f. Dining Panili dan Lawang Rare}

Kata dining 'dinding' + panili (paN + tili) 'penutup' merupakan dinding pembatas pandangan dari lunyuk agung ke ruang dalam. Dahulu, antara laki-laki dan perempuan tidak boleh bebas berbaur, sehingga dibuatlah dining panili. Konsep dining panitili juga tidak bisa dilepaskan dari konsep keislaman yang tidak memperkenankan laki-laki dan perempuan membaur untuk menghindari fitnah yang tidak diinginkan.

Lawang 'pintu' + rare pintu gerbang yang terletak di halaman antara mesjid kesultanan dan istana Dalam Loka. Lawang rare ini menjadi perlintasan utama dari istana menuju mesjid. Hal tersebut sebagai tanda bahwa pemimpin dalam menjalankan amanah harus selalu sesuai dengan perintah agama.

\section{g. Bale Pamaning dan Sarumung Belo}

Bale 'rumah' + pamaning (pa + maning) merupakan bangunan tempat mandi sultan dan keluarga'. Sementara sarumung 'kamar mandi' + belo 'panjang' adalah kamar mandi bagi penghuni istana dan untuk tamu istana.

\section{Konteks Budaya Bentuk-Bentuk}

Terminologi dalam Rumah Adat Dalam

\section{Loka Sumbawa}

Rumah adat Dalam Loka Sumbawa menyiratkan keberadaan sebuah pradaban dan sistem pemerintahan dan sitem kerajaan dalam bentuk aristokrasi. Tatanan pemerintahan yang bertumpu pada raja (sultan) adalah sebuah sistem yang mencakup adat, pemerintahan dan hukum. Oleh karena itu, hal-hal yang berkaitan dengan sikap budaya masyarakat Sumbawa yang dianggap memiliki hubungan dengan bentuk-bentuk terminologi dalam rumah adat Dalam Loka Sumbawa dapat diuraikan sebagai berikut. 
a. Bala rea, bala bulo dan sarapo kamutar sebagai hasil dari budaya gotong royong masyarakat Sumbawa

Bala rea, bala bulo dan sarapo kamutar merupakan beberapa bagian dari bentukbentuk terminologi yang melekat dalam rumah adat Dalam Loka. Bala rea merupakan bangunan utama istana Dalam Loka, dibangun dengan kayu jati sebagai pengganti kediaman raja yang dulu pernah terbakar saat terjadi letusan bubuk mesiu kerajaan. Bala rea menghadap ke arah selatan, penentuan arah selatan disesuaikan dengan pertimbangan hukum arah mata angin. Selatan dipercaya dapat memberikan suasana sejuk, tenteram, damai, dan nyaman. Tidak hanya itu, dalam persfektif masyarakat Sumbawa, selatan juga bermakna menatap pada masa lalu yang bila diartikan pemimpin harus memiliki kebijaksanaan dan kearifan dalam menyikapi masa lalu yang bisa dibawa ke masa kini.

Bala bulo, merupakan bangunan pendukung yang digunakan oleh putra-putri sultan bermain, dan sarapo kamutar merupakan bangunan pendukung yang dibangun ketika akan dilaksanakan acaraacara adat, seperti perkawinan, upacara tolak bala, dan lain sebagainya. Pembangunan bala rea, bala bulo dan sarapo kamutar dalam prosesnya selalu melibatkan rakyat sebagai bentuk rasa memiliki, pengakuan dan dedikasi terhadap pemerintahan Sultan Sumbawa. Keikutsertaan rakyat dalam proses pembangunan tersebut dapat dilihat sebagai wujud dari budaya gotong royong yang melekat dalam kehidupan masyarakat Sumbawa.

Dalam perspektif sosiologi budaya, nilai gotong royong adalah semangat yang diwujudkan dalam bentuk perilaku atau tindakan individu yang dilakukan tanpa mengharap balasan untuk melakukan sesuatu secara bersama-sama demi kepentingan bersama atau individu tertentu. Masyarakat Sumbawa sadar bahwa gotong royong menjadikan kehidupan manusia Sumbawa lebih berdaya dan sejahtera. Dengan bergotong royong, berbagai permasalahan kehidupan bersama bisa terpecahkan secara mudah dan murah..

b. Lawang rare sebagai wujud dari sikap religi masyarakat Sumbawa

Keberadaan lawang rare (gerbang khusus menuju mesjid Agung) menandai betapa agama memiliki posisi dan peranan yang sangat penting dalam kehidupan tau Samawa. Agama dapat berfungsi sebagai faktor motivasi (pendorong untuk bertindak yang benar, baik, etis, dan maslahat), profetik (menjadi risalah yang menunjukan arah kehidupan), kritik (menyuruh pada yang ma'ruf dan mencegah dari yang mungkar), kreatif (mengarahkan amal atau tindakan yang menghasilkan manfaat bagi diri sendiri dan orang lain), intergratif (menyatukan elemen-elemen yang rusak dalam diri manusia dan masyarakat untuk menjadi lebih baik), sublimatif (memberikan proses penyucian diri dalam 
kehidupan), dan liberatif (membebaskan manusia dari berbagai belenggu kehidupan). Manusia yang tidak memiliki pandangan hidup, lebih-lebih yang bersumber agama, ibarat orang buta yang berjalan di tengah kegelapan dan keramaian: tidak tahu dari mana dia datang, mau apa di dunia, dan ke mana tujuan hidup yang hakiki.

\section{Pamuji tentu lako nene \\ No bau tu kamaeng \\ Ada pang tu bajele}

Ling dunia pang tu nanam

Pang akhirat pang tu matak

Ka tu boat po ya ada

Na asi mu samogang

Paboat aji ko Nene'

Gama kerik slamat dunia akhirat

Cuplikan lawas di atas menjelaskan bahwa agama dalam kehidupan tau Samawa merupakan sesuatu yang mendasar yang dijadikan pandangan atau pedoman hidup. Puja dan puji hanya kepada Tuhan, tidak bisa kita miliki, hanya kepada-Nya tempat bersandar.

\section{c. Bale pamaning dan sarubung belo}

wujud dari budaya bersih dan cinta

lingkungan

Kebersihan adalah upaya manusia untuk memelihara diri dari segala sesuatu yang kotor, dalam rangka mewujudkan dan
Masyarakat Sumbawa menyadari betul bahwa sikap dan nilai-nilai ketuhanan harus senantiasa terinternalisasi dalam diri, sehingga ketaatan dan pemahaman tentang agama akan didapatkan secara utuh. Sebagai sesuatu yang hidup dalam ruang sosial, nilai-nilai tentang ketuhanan juga diperkuat dengan keberadaan lawas (sastra lisan tradisional Sumbawa) yang bertemakan agama seperi di bawah ini.

'Puja dan puji hanya kepada tuhan'

'Tidak akan bisa kita miliki'

'Ada pada-Nya tempat bersandar'

'Di dunia tempat menanam'

'Di akhirat tempat menuai'

'Setelah berbuat baru mendapatkan hasil'

'Jangan kamu menganggap remeh'

'mengabdi kepada Allah'

'Demi keselamatan dunia akhirat'

melestarikan kehidupan yang sehat dan nyaman. Kesadaran akan pentingnya tempat bercuci sebenarnya telah melekat pada diri setiap insan, semua sadar bahwa kenyamanan dalam melaksanakan ibadah di antaranya apabila rukun dan syaratnya terpelihara, bercuci merupakan bagian dari yang dimaksud.

Keberadaan bale pamaning (tempat mandi khusus sultan) dan sarubung belo (kamar mandi untuk tamu dan penghuni istana) menjadi bukti bahwa dari dulu masyarakat Sumbawa sudah berusaha hidup bersih dan mencintai lingkungan dengan 
tidak melakukan aktivitas mandi dan buang air di sungai atau tempat terbuka. Hal tersebut sejalan dengan perintah agama yang dianut untuk melakukan hidup bersih dan tidak membuat kerusakan di muka bumi. Hidup bersih dapat membuat fisik dan mental menjadi sehat, memantapkan keimanan dan ketakwaan, perilaku terpuji serta lingkungan yang nyaman dan menyenangkan. Termasuk dalam bersih jasmani antara lain; bersih anggota badan, pakaian, tempat tinggal, lingkungan dan peralatan yang digunakan dalam kehidupan sehari-hari dari segala najis dan kotoran, sedangkan bersih rohaniah antara lain termasuk bersih hati, pikiran, perasaan, sikap, ucapan dan segala perbuatan tercela atau dosa, baik dosa kecil maupun dosa besar.

d. Lunyuk emas dan tete sawai sebagai bentuk penghormatan terhadap kaum perempuan

Keberadaan lunyuk emas (sebagai tempat musyawarah khusus perempuan) dan tete sawai (sebagai tangga khusus perempuan karena berada di belakang bala rea) menjadi bukti adanya perhatian, dan pengakuan akan pentingnya eksistensi perempuan. Pada tahun 1930-an - 1980-an wanita Sumbawa sangat terkenal dengan sebutan "lala jinis" artinya wanita yang benar-benar menjadi harapan dan pilihan karena tekad perjuangan, menjaga martabat dan membantu sesama.

Sesuai dengan ajaran agama yang dianut, Islam telah menghormati wanita dalam makna yang sebenarnya. Bila bersandar pada peran ibu dan kehormatan ibu di dalam rumah tangga atau bertopang pada peran wanita, pengaruh wanita, hakhak wanita dan batas-batasan wanita di dalam rumah tangga, sama sekali bukan berarti melarang wanita dari berpartisipasi dalam urusan sosial dan ikut campur dalam perjuangan dan aktivitas umum. Wanita bagi tau Samawa dalam rumah tangga begitu mulia dan terhormat dan merupakan poros menajemen dalam rumah tangga, lilin bagi semua anggota keluarga, sumber keakraban, ketenangan dan ketentraman.

Lebih jauh, dalam kehidupan sosial masyarakat Sumbawa terdapat sebuah tradisi yang memiliki nuansa begitu kuat kaitannya dengan penghormatan terhadap perempuan, tradisi yang dimaksud biasa dikenal dengan istilah tama lamung. Tradisi tama lamung adalah sebuah acara adat yang dilakukan untuk wanita Sumbawa mulai dari usia remaja hingga dewasa sebagai upaya menjaga nilai moralitas yang terkandung dalam kehidupan sehari-hari. Tradisi tama lamung merupakan simbol, etika atau biasa disebut budaya ila 'malu', yang artinya wanita Samawa dapat memegang teguh pendirian, harga diri dan martabatnya sebagai perempuan agar memiliki rasa malu. Tama lamung juga dianggap sebagai salah satu usaha agar wanita-wanita Sumbawa lebih dapat merespon perubahan secara terbuka dan positif, seperti menghargai tata kesopanan, menjauhi prilaku hedonis, materialis dan 
seronok.

Tradisi tama lamung masih relevan dalam kehidupan sekarang, tentu akan banyak memberi manfaat dan solidaritas sebagai praksis sistem sosial (sosiological) masyarakat guna menghindari malapetaka bagi wanita, seperti pemerkosaan, asusila, dan hubungan seks bebas. Pada beberapa keluarga tradisi tama lamung masih tetap dipertahankan karena dianggap masih dianggap berguna dalam kelangsungan hidup masyarakat. Namun secara umum dalam perkembangannya tradisi tama lamong ini perlahan mulai hilang disebabkan karena tidak adanya proses edukasi secara mendalam tentang filosofifilosofi luhur yang terdapat di dalamnya.

Laki-laki di Sumbawa sejatinya menyadari penuh bahwa menghargai perempuan bukan berarti perempuan membutuhkan belas kasihan. Penghargaan dapat berupa memberikan kebebasan sewajarnya, tidak menganggap perempuan sebagai kelas kedua, tidak melakukan marjinalisasi atau kekerasan baik fisik/ nonfisik, tidak melakukan pelecehan seksual, pemberlakuan sistem yang humanis, serta menempatkan perempuan sebagai partner yang baik.

\section{e. Paladang, pemarkah budaya masyarakat}

Sumbawa dalam hal menghormati tamu

Secara istilah bertamu merupakan kegiatan mengunjungi rumah sahabat, kerabat ataupun orang lain, dalam rangka menciptakan kebersamaan dan kemaslahatan bersama. Dengan bertamu seorang bisa menjalin persaudaraan bahkan dapat menjalin kerjasama untuk meringankan berbagai masalah yang dihadapi dalam kehidupan. Ada kalanya seorang bertamu karena adanya urusan yang serius, sekedar bertandang, karena lama tidak bertemu (berjumpa) ataupun sekedar untuk mampir sejenak. Dengan bertangang ke rumah kerabat atau sahabat, maka kerinduan terhadap kerabat ataupun sahabat dapat tersalurkan, sehingga jalinan persahabatan menjadi kokoh.

Pada kehidupan masyarakat Sumbawa, menghormati tamu sangat dianjurkan. Paladang disediakan sebagai tempat khusus menerima tamu walau untuk sekadar menunggu tuan rumah. Sebagi contoh, Paladang digunakan oleh penghuni rumah untuk menerima tamu laki-laki jika suami dari yang punya rumah sedang tidak berada di tempat misalnnya pergi ke sawah, ladang, dan lain-lain. Hal tersebut dilakukan agar tidak terjadi fitnah, jikalaupun tiba waktunya makan, tamu tersebut diperbolehkan masuk tapi hanya sebatas sampai ruang tamu, itupun harus ada orang lain yang menemani, misalnya saudara laki-laki, ipar, atau tetangga.

Bertamu merupakan kebiasaan positif dalam kehidupan bermasyarakat dari zaman dahulu hingga sekarang. Sesuai dengan ajaran yang dianut bahwa masyarakat Sumbawa memahami persoalan tamu dan bertamu dalam beberapa hal. 1) Tamu membawa rizki dan kepulangannya membawa ampunan bagi tuan rumah, 2) 
Sejelek-jeleknya suatu kaum adalah yang tidak menghormati tamunya, 3) Tidak ada kebaikan seseorang yang tidak dikunjungi tamu. Oleh karenanya, masyarakat Sumbawa pada umumnya akan merasa sedih jika dalam kurun waktu yang cukup lama tidak ada tamu yang bertandang ke rumanya.

\section{f. Tete gasa sebagai wujud dari budaya menghormati pemimpin}

Dalam tatanan etnis Samawa masa lampau, raja atau sultan adalah pemegang kekuasaan pemerintahan dan kemasyarakatan. Pada hakikatnya, jabatan tersebut semata-mata adalah amanat (amanah) dari Yang Maha Kuasa dan diakui oleh seluruh rakyat. Walaupun ada jabatan-jabatan setingkat di bawah sultan seterusnya secara hirarkis ke bawah namun tidak membatasi interaksi di antaranya. Keberadaan tetegasa yang digunakan sebagai tangga utama untuk naik atau turun ke dalam bala rea berbeda dengan tangga biasa pada umumnya, tangga tersebut berupa lantai kayu yang dimiringkan hingga menyentuh tanah dan lantai kayu tersebut ditempeli oleh potongan kayu sebagai penahan pijakan. Tetegasa berasal dari kata, 'tete' yang berarti titian dan 'gasa' yang berarti ganjil. Jadi secara harfiah, tetegasa adalah titian dalam jumlah ganjil yang digunakan untuk menyebrang dari suatu tempat ke tempat yang lain. Pada Tetegasa terdapat dua puluh lima anak tangga yang menandakan jumlah nabi dan rasul dalam agama
Islam. Tetegasa dibuat dengan konsep 'peruak' (tanjakan) sehinggak saat berjalan di atasanya posisi badan sedikit merunduk sebagai bentuk penghormatan terhadap sultan sebagai pemimpin rakyat.

Sebenarnya dalam budaya etnis manapun penghormatan terhadap pemimpin adalah sebuah keharusan karena posisi dan peranan pemimpin sangat menentukan kelangsungan hidup suatu masyarakat. Demikian pula peranan masyarakat yang dipimpin juga sangat menentukan. Beruntung tau Samawa karena adat istiadatnya senantiasa sejalan dengan agama anutan; "adat bersendikan sara, sara bersendikan kitabullah" artinya, segenap tingkah laku individu harus sesuai dengan adat istiadat, dan seluruhnya mengacu kepada tuntunan Al-Quran dan Al Hadist. Orang yang keluar dari tuntunan adat istiadat disebut " $t a u$ no to basa" yaitu orang tidak tahu aturan. Setiap insan yang mengaku tau Samawa menyadari diri sebagai pemimpin, sehingga interaksi personal baik antara yang memimpin dan dipimpin adalah pengemban amanah kekhalifaan. Bagi tau Samawa menghormati pemimpin adalah bagian dari definisi kepemimpinan itu sendiri. Ungkapan dalam bahasa Samawa "ada kena tu dadi otak beretik daripada tu dadi elong baloq" artinya, lebih baik menjadi kepala cicak daripada menjadi ekor buaya. Maksud tersebut menjelaskan ekspresi nyata dari keharusan menjadikan diri sebagai pemimpin sekalipun itu hanya sebagai 'kepala cicak'. Hanya saja, orang sering menilai hal 
tersebut secara tidak proporsional sehingga seringkali muncul sikap-sikap sok gengsi, terlalu percaya diri, pemalas, tidak kreatif dan tidak mau tampil mendahului untuk merebut kesempatan..

\section{g. Terminologi lunyuk agung sebagai pemarkah budaya musyawarah}

Keberadaan lunyuk agung sebagai ruangan khusus tempat musyawarah di istana tempat pusat pemerintahan kesultanan menunjukan bahwa aktivitas bermusyawarah sudah berlangsung lama di Sumbawa. Dalam kehidupan masyarakat luas, kegiatan musyawarah juga termanifestasi dalam budaya tokal adat dan tokal keluarga. Tokal adat adalah rembuk bersama atau musyawarah untuk membicarakan perihal rencana suatu hajatan berupa pesta atau kegiatan kemasyarakatan. Tokal adat sebenarnya juga bagian dari tradisi saling membantu pada saat salah seorang kerabat, keluarga, atau masyarakat akan melangsukan hajatan. Tokal adat tujuannya untuk meringankan biaya yang akan dikeluarkan oleh masyarakat yang akan melangsungkan hajatan misalnya perkawinan, sunatan, ataupun hajatan lainnya.

Warisan tradisi musyawarah dapat menjadi modal masyarakat Sumbawa untuk mempererat rasa kekeluargaan mengingat masyarakatnya yang berasal dari berbagai daerah di Indonesia. Tokal adat diharapkan sebagai wahana untuk memperkokoh persatuan di antara masyarakat yang berbeda suku bangsa ini. Saat ini tinggal beberapa wilayah saja yang masih melaksanakan acara tokal adat. Hal ini tergantung dari kebijakan pemerintah desa serta adanya kesepakatan di antara warga masyarakat setempat. Ke depannya, semoga tokal adat akan tetap terpelihara dan bertahan dalam masyarakat Sumbawa, supaya nilai-nilai budaya dan kearifan lokal yang ada dapat dipertahankan.

\section{SIMPULAN}

Setelah semua tahap penelitian dilakukan, mulai pengumpulan data, pengolahan dan analisis data, pada akhirnya peneliti dapat menyimpulkan hasil penelitian tentang terminologi dalam rumah adat Sumbawa: Sebuah tinjauan antropolinguistik, yakni; ditemukan sebanyak lima belas (15) bentuk-bentuk terminologi yang terdapat dalam rumah adat sumbawa (Dalam Loka). Beberapa bentuk terminologi dalam rumah adat Sumbawa seperti repan shalat, lawang rare, lunyuk agung, lunyuk emas, alang aji, alang kamutar, paladang, tete gasa, tete sawai dan tiang kuntung adalah cerminan dari sistem nilai budaya yang melahirkan perilaku komunal dalam tatanan kehidupan masyarakat Samawa, seperti budaya gotong royong, musyawarah, toleransi, budaya menghormati tamu, budaya bersih dan cinta lingkungan, sikap religi, serta budaya menghormati pemimpin.. 


\section{UCAPAN TERIMAKASIH}

Penulis mengucapkan terima kasih kepada Mitra Bebestari atas kritik dan masukan yang membangun untuk perbaikan artikel ini.

\section{DAFTAR PUSTAKA}

Beratha, S.N. L. 1998. "Materi Kajian Linguistik Kebudayaan dalam Linguistika”. Program Magister (S2) Linguistik Universitas Udayana Tahun V, Edisi ke Sembilan, September 1998, PP $41-45$.

Budiharjo, E. 1994. Percikan Masalah Arsitektur, Perumahan Perkotaan. Yogyakarta: Gajah Mada University Press.

Chaer. A. 2007. Leksikologi \& Leksikografi Indonesia. Jakarta: Rineka Cipta.

Frick, H. 2008. Ilmu Fisika Bangunan. Yogyakarta: Kanisius.

Halliday, M.A.K. 1978. Language and Social Semiotics: The Social Interpretation of Language and Meaning. London:Edward Arnold.

Halliday, M.A.K. dan Ruqaiya Hasan. 1994. Context and Text: Aspect of Language in a Social Semiotic Perpectivese. Geelong: Deakin University Press.

Haryadi dan Setiawan, B. 2010. Arsitektur Lingkungan dan Perilaku. Yogyakarta: Gadjah. Mada University Press.

Koentjaraningrat, 2009. Pengantar Ilmu Antropologi. Jakarta: Rineka Cipta.

Koentjono, D. 1982. Dasar-Dasar Lingustik Umum. Jakarta: Fakultas Sasra.

Kridalaksana, Harimurti. 2008. Kamus Linguistik. Jakarta: Gramedia Pustaka Utama.
Mahsun, 2005. Metode Penelitian Bahasa: Tahapan Strategi Metode dan Tekhniknya. Jakarta: Raja Grafindo Persada.

Mahsun. 2007. Metodologi Penelitian Bahasa: Tahap Strategi, Metode dan Tekniknya. Jakarta: Raja Grafindo Persada.

Masinambow, E.K.M. 1998. "Linguistik: Masuk Ilmu Pengetahuan Apa? dalam Linguistika”. Program Magister (S2) Linguistik Universitas Udayana. Tahun V Edisi Kesembilan September 1998, PP. $10-20$.

Mbete, Aron. M. 2009. "Problematika Keetnikan dan Kebahasaan dalam Perspektif Ekolinguistik". Seminar Nasional Budaya Etnik III: Universitas Udayana.

Pusat Bahasa. 2009. Kamus Bahasa SumbawaIndonesia. Departemen Pendidikan Nasional Kantor Bahasa Provinsi NTB.

Pusat Bahasa. 2012. Kamus Besar Bahasa Indonesia. Jakarta: Gramedia Pustaka.

Riana, I.K. 2003. "Linguistik Budaya: Kedudukan dan Ranah Pengkajiannya". Pidato Pengukuhan Jabatan Guru Besar Tetap dalam Bidang Ilmu Linguistik Budaya Fakultas Sastra Universitas Udayana. Denpasar: Universitas Udayana.

Santoso, B. 2003. Pengantar Ilmu Hukum Pajak. Bandung: Refika Aditama.

Sibarani, R. dan Henry Guntur Tarigan (Penyunting). 1993. Makna Nama dalam Bahasa Nusantara: Sebuah Kajian Antropolinguistik. Bandung: Bumi Siliwangi.

Sibarani, Robert. 2004. Antropolinguistik. Medan: Poda.

Suriasumantri, J.S. 1996. Filsafat Ilmu Sebuah Pengantar Populer. Jakarta: Pustaka Sinar Harapan. 